Volume 3 Nomor 1, Januari-Juni 2019: hlm. 27-34.

Magister Ilmu Hukum, Fakultas Hukum, Universitas Lampung,

Bandar Lampung, Lampung, Indonesia.

E-ISSN: 2598-3105 P-ISSN: 2723-2581

http://jurnal.fh.unila.ac.id/index.php/cepalo

\title{
PENYELENGGARAAN PENDAFTARAN PERALIHAN HAK MILIK ATAS HARTA BERSAMA DI KANTOR PERTANAHAN KABUPATEN LAMPUNG TIMUR
}

\section{IMPLEMENTATION OF REGISTRATION OF OWNERSHIP RIGHTS FOR JOINT ASSETS IN THE EAST LAMPUNG REGENCY LAND OFFICE}

\author{
Reny Raymond Diaz \\ Badan Pertanahan Nasional \\ reny.diaz87@gmail.com
}

\begin{abstract}
Abstrak
Pasal 37 ayat (1) PP 24 Tahun 1997 menyatakan bahwa peralihan hak milik atas tanah hanya dapat didaftarkan jika dibuktikan dengan akta PPAT. Akta PPAT memiliki kekuatan pembuktian sempurna karena mетиаt sетиа unsur alat bukti perdata sehingga tidak memerlukan dokumen lain sebagai dasar pendaftaran hak. Hal ini dipertegas dengan Peraturan Kepala BPN Nomor 1 Tahun 2010, pada kenyataannya, kepala kantor pertanahan tidak serta merta mau menerima akta sebagai bukti peralihan satusatunya untuk dijadikan dasar pendaftaran peralihan hak. Kepala kantor mewajibkan penambahan dokumen berupa fotokopi buku nikah, fotokopi akta cerai, perjanjian perkawinan, dan/atau surat persetujuan para ahli waris jika salah satu pasangan suami/istri telah meninggal dunia. Penelitian ini bertujuan untuk mengetahui penyelenggaraan pendaftaran peralihan hak milik atas harta bersama perkawinan. Penelitian menggunakan metode penelitian yuridis normatif empiris. Pendekatan penelitian menggunakan pendekatan perundang-undangan, analitis dan partisipasi. Analisis data menggunakan data primer dan sekunder untuk diambil kesimpulan menggunakan logika induktif.

Hasil penelitian menunjukkan bahwa: 1) penyelenggaraan pendaftaran peralihan hak milik atas harta bersama memungkinkan adanya diskresi karena perundang-undangan yang mengatur tidak lengkap dan jelas. 2) Akta PPAT belum dapat memberikan jaminan kepastian hukum sepenuhnya dalam pendaftaran tanah sehingga masih memerlukan dokumen lain sebagai pelengkap pembuktian. 3) Upaya Kantor Pertanahan dalam memberikan jaminan kepastian hukum sertipikat adalah dengan menerapkan persyaratan dokumen tambahan dalam pendaftaran peralihan hak milik atas harta bersama.
\end{abstract}

Kata Kunci: Akta PPAT, Harta Bersama, Hak Milik, Peralihan Hak

\begin{abstract}
Article 37 paragraph (1) PP 24 of 1997 states that the transfer of ownership rights over land can only be registered if proven by a PPAT deed. The PPAT Deed has the strength of perfect proof because it contains all elements of civil evidence so that it does not require other documents as a basis for registration of rights. This is confirmed by the Regulation of the Head of BPN Number 1 of 2010, in fact, the head of the land office does not necessarily want to accept the deed as the only proof of transfer to serve as the basis for registering the transfer of rights. The head of office requires the addition of documents in the form of a photocopy of a marriage book, a photocopy of a divorce certificate, marriage agreement, and / or a letter of approval from the heirs if one of the spouses has died.

This study aims to determine the implementation of the transfer of ownership rights over joint property marriage. The research uses empirical normative juridical research methods. The research approach uses a statutory, analytical and participatory approach. Data analysis uses primary and secondary data to conclude using inductive logic. The results of the study show that: 1) the registration of the transfer of ownership of the joint property allows discretion because the laws governing it are incomplete and unclear. 2) Deed of PPAT has not been able to provide a guarantee of full legal certainty in land registration so that it still requires other documents as a complementary proof. 3) Efforts by the Land Office in providing guarantees of legal certainty of certificates are by applying additional document requirements in the registration of the transfer of ownership of shared assets.
\end{abstract}


Keywords: PPAT Deed, Joint Assets, Property Rights, Transfer of Rights.

Cara Mengutip (How to Cite): Reny Raymond Diaz, "Penyelenggaraan Pendaftaran Peralihan Hak Milik Atas Harta Bersama di Kantor Pertanahan Kabupaten Lampung Timur”, Jurnal Cepalo, 3 (1), (2019): 27-34.

DOI: https://doi.org/10.25041/cepalo.v3no1.1787

\section{A. Pendahuluan}

Salah satu kegiatan pendaftaran tanah adalah pendaftaran peralihan hak milik atas tanah. Berdasarkan Pasal 26 Undang-Undang Nomor 5 Tahun 1960 tentang Peraturan Dasar Pokok-Pokok Agraria (UUPA) menyatakan bahwa jual-beli, penukaran, penghibahan, pemberian dengan wasiat, pemberian menurut adat dan perbuatan-perbuatan lain yang dimaksudkan untuk memindahkan hak milik serta pengawasannya diatur dengan Peraturan Pemerintah. Pasal ini menyiratkan bahwa pemerintah dianggap perlu menetapkan peraturan pemerintah tersendiri yang khusus mengatur mengenai peralihan hak atas tanah dengan tujuan tertentu. ${ }^{1}$

Dalam kenyataannya, sampai saat ini peraturan pemerintah yang khusus mengatur mengenai peralihan hak milik atas tanah belum ada. Pelaksanaan pendaftaran peralihan hak milik atas tanah masih berpedoman kepada beberapa peraturan perundangan yaitu: mengenai tata cara pendaftaran peralihan hak dilaksanakan menurut Peraturan Pemerintah Nomor 24 Tahun 1997 dan Peraturan Menteri Negara Agraria/Kepala Badan Pertanahan Nasional Nomor 3 Tahun 1997 tentang Pendaftaran Tanah, sedangkan mengenai persyaratan pendaftaran dilaksanakan menurut Peraturan Kepala Badan Pertanahan Nasional Nomor 1 Tahun 2010 tentang Standar Pengaturan dan Pelayanan Pertanahan (PERKABAN Nomor 1 Tahun 2010).

Berdasarkan PERKABAN Nomor 1 Tahun 2010 menyatakan bahwa peralihan hak milik atas tanah memiliki jangka waktu pendaftaran selama lima hari kerja dengan persyaratan meliputi: formulir permohonan, surat kuasa bila dikuasakan, fotokopi identitas penjual dan pembeli, sertipikat, akta PPAT, fotokopi SPPT PBB, bukti pembayaran pajak peralihan hak serta ijin pemindahan hak bila diperlukan. Peraturan ini secara tersirat menyatakan bahwa bukti peralihan hak atas tanah yang dipersyaratkan adalah cukup akta PPAT saja. Hal senada diatur dalam Pasal 37 ayat (1) PP Nomor 24 Tahun 1997 yang menyatakan bahwa peralihan hak atas tanah dan hak milik atas satuan rumah susun melalui jual beli, tukar menukar, hibah, pemasukan dalam perusahaan dan perbuatan hukum pemindahan hak lainnya, kecuali pemindahan hak melalui lelang hanya dapat didaftarkan jika dibuktikan dengan akta yang dibuat oleh PPAT yang berwenang menurut perundang-undangan yang berlaku. Dengan demikian, akta PPAT yang kelak akan menjadi alat bukti satu-satunya apabila suatu saat terjadi sengketa tanah, dianggap sudah dapat memberi jaminan kepastian hukum pemegang hak atas tanah.

Pada kenyataannya, berdasarkan hasil pengamatan, di Kantor Pertanahan Kabupaten Lampung Timur, kepala kantor tidak serta merta mau menerima akta PPAT sebagai bukti peralihan satu-satunya untuk pendaftaran peralihan hak milik atas tanah yang berasal dari harta bersama perkawinan. Kepala kantor mewajibkan adanya penambahan persyaratan berupa fotokopi buku nikah, fotokopi akta cerai, perjanjian perkawinan bila ada, surat keterangan kepala desa letak tanah bahwa tanah dibeli oleh pemohon merupakan harta bersama, dan/atau surat pernyataan yang menerangkan mengenai persetujuan dari para ahli waris jika salah satu pasangan suami/istri telah meninggal dunia.

Dalam menyelenggarakan pendaftaran peralihan hak milik atas tanah bersama dari perkawinan, kantor pertanahan berpedoman pada Undang-Undang Nomor 30 Tahun 2014 tentang Administrasi Pemerintahan. Hal ini berkaitan dengan kedudukan sertipikat sebagai Keputusan Tata Usaha Negara (KTUN) bersifat final, individual dan konkret. Sebagai KTUN, sertipikat merupakan alat bukti mutlak lahirnya keadaan hukum baru yang mengakibatkan lahirnya hubungan hukum dan kewajiban tertentu. ${ }^{2}$ Sertipikat memiliki unsur deklaratif berarti suatu keputusan yang bersifat mengikatnya suatu hubungan hukum yang sebelumnya memang telah

\footnotetext{
${ }^{1}$ Penjelasan Pasal 26 dan Penjelasan Umum II angka 6 UU Nomor 5 Tahun 1960 tentang Peraturan Dasar Pokok-Pokok Agraria mneyatkan bahwa tujuan dibuatnya peraturan pemerintah secara khusus yang mengatur tentang peralihan hak atas tanah adalah untuk melindungi pihak ekonomis lemah dari monopoli tanah.

${ }^{2}$ Philipus M. Hardjon, R. Sri Soemantri, Sjachran Basah, Bagir Manan, H.M Laica Marzuki, J.B.J.M. Ten Berge, P.J.J. van Buuren dan F.A.M Stroink, Pengantar Hukum Administrasi Negara, Cetakan III, (Yogyakarta: Gajah Mada University Press, 1994), hlm. 144.
} 
ada. ${ }^{3}$ Untuk itulah diperlukan penerapan asas kecermatan yang berarti bahwa suatu keputusan atau tindakan harus didasarkan pada informasi dan dokumen yang lengkap untuk mendukung legalitas.

Di lain sisi, masyarakat dan/atau PPAT yang merupakan pemohon pendaftaran peralihan hak milik atas harta bersama, menganggap bahwa penambahan dokumen persyaratan tidak diperlukan. Akta PPAT memiliki kekuatan pembuktian sempurna secara perdata sehingga tidak memerlukan dokumen lain sebagai dasar pendaftaran peralihan hak atas tanah. Di dalam akta PPAT telah termasuk semua unsur bukti yang meliputi: tulisan, saksi, persangkaan, pengakuan, dan sumpah. ${ }^{4}$ Mekanisme pendaftaran peralihan hak milik atas atas harta bersama dianggap berbelit dan tidak memiliki kepastian pelayanan sesuai dengan asas penyelenggaraan pelayanan publik yang tercantum pada Pasal 4 Undang-Undang Nomor 25 Tahun 2009 tentang Pelayanan Publik. Asas akuntabilitas, kecepatan, kemudahan, dan keterjangkauan lebih menekankan pada proses penyelenggaraan pelayanan harus dapat dipertanggungjawabkan sesuai ketentuan perundangundangan, tepat waktu sesuai standar pelayanan dan dilakukan secara cepat, mudah dan terjangkau.

Perbedaan pemahaman antara kantor pertanahan sebagai penyedia layanan publik dengan masyarakat dan PPAT sebagai pengguna layanan menyebabkan adanya miskomunikasi yang dapat mengakibatkan tersendatnya penyelenggaraan pendaftaran peralihan hak milik atas harta bersama di Kantor Pertanahan Kabupaten Lampung Timur. Berdasarkan latar belakang tersebut maka diperlukan adanya penelitian tentang "Penyelenggaraan Pendaftaran Peralihan Hak Milik Atas Harta Bersama di Kantor Pertanahan Kabupaten Lampung Timur". Secara umum, tujuan dari penelitian ini adalah untuk menganalisis: a) penyelenggaraan pendaftaran peralihan hak milik atas harta bersama perkawinan, b) kekuatan pembuktian akta PPAT dalam memberikan jaminan kepastian hukum pendaftaran peralihan hak atas tanah, dan c) upaya yang dapat dilakukan oleh kantor pertanahan dalam memberikan jaminan kepastian hukum terhadap sertipikat hak atas tanah.

Penelitian menggunakan metode penelitian yuridis normatif empiris. Pendekatan yang digunakan adalah pendekatan perundang-undangan, analitis, dan partisipasi. Pengumpulan data dilakukan dengan cara studi dokumen, observasi dan wawancara. Data kemudian diklasifikasi dan dianalisis untuk disajikan dalam bentuk deskriptif analitis.Secara umum, tujuan dari penelitian ini adalah untuk menganalisis: a) penyelenggaraan pendaftaran peralihan hak milik atas harta bersama perkawinan, b) kekuatan pembuktian akta PPAT dalam memberikan jaminan kepastian hukum pendaftaran peralihan hak atas tanah, dan c) upaya yang dapat dilakukan oleh kantor pertanahan dalam memberikan jaminan kepastian hukum terhadap sertipikat hak atas tanah.Penelitian menggunakan metode penelitian yuridis normatif empiris. Pendekatan yang digunakan adalah pendekatan perundang-undangan, analitis, dan partisipasi. Pengumpulan data dilakukan dengan cara studi dokumen, observasi dan wawancara. Data kemudian diklasifikasi dan dianalisis untuk disajikan dalam bentuk deskriptif analitis.

\section{B. Pembahasan}

\section{Penyelenggaraan Pendaftaran Peralihan Hak Milik atas Harta Bersama dari Perkawinan}

Hukum positif di Indonesia memiliki pengertian dan prinsip berbeda mengenai harta bersama. Pasal 119 Kitab Undang-Undang Hukum Perdata (KUH Perdata) menyatakan bahwa harta bersama sebagai suatu persatuan bulat antara harta kekayaan suami dan istri meliputi seluruh harta dan utang yang mulai ada sejak perkawinan dilangsungkan, kecuali ditentukan lain melalui perjanjian perkawinan. Dalam hal kekuasaan untuk bertindak melakukan perbuatan hukum, menurut Pasal 124 KUH Perdata, suami dapat mengalihkannya tanpa memerlukan persetujuan istri. Pengaturan ini dapat diartikan bahwa tidak ada pengakuan terhadap harta bawaan karena semua harta melebur menjadi harta bersama setelah perkawinan berlangsung kecuali ditentukan lain melalui perjanjian perkawinan.

Berbeda halnya dengan prinsip pada Undang-Undang Nomor 1 Tahun 1974 tentang Perkawinan dan Kompilasi Hukum Islam yang mengakui adanya harta bersama dan sekaligus adanya harta bawaan yang sudah ada sebelum pernikahan. Pasal 35 ayat (1) UU Perkawinan dan Pasal 85 Kompilasi Hukum Islam (KHI) menyatakan bahwa harta bersama adalah harta yang diperoleh selama masa perkawinan namun tidak menutup adanya kemungkinan adanya harta milik masing-masing suami atau istri. ${ }^{5}$ Suami atau istri hanya dapat

\footnotetext{
${ }^{3}$ Putusan MA Nomor: 140 K/TUN/2000 tanggal 11 Februari 2002 yang menyatakan: sertipikat tanah termasuk keputusan TUN deklaratoir, artinya dibalik kekuasaan tersebut terdapat pemegang hak yang sebenarnya (de ware rechtstitel). Contohnya pada peralihan hak jual-beli, hibah, waris, dan sebagainya.

${ }^{4}$ Habib Adjie, Kebatalan dan Pembatalan Akta Notaris, Bandung: Refika Aditama, (2013), hlm 6.

${ }^{5}$ Pasal 35 ayat (2) Undang-Undang Nomor 1 Tahun 1974 tentang Perkawinan.
} 
melakukan perbuatan hukum mengalihkan hak dengan persetujuan kedua belah pihak. Perkawinan tidak merubah status kepemilikan hak atas harta kekayaan tersebut menjadi hak milik bersama. Harta isteri tetap menjadi hak isteri dan dikuasai penuh olehnya, demikian juga harta suami tetap menjadi hak suami dan dikuasai penuh olehnya. ${ }^{6}$

Penentuan mengenai harta bersama akan berpengaruh pada mekanisme pendaftaran tanah. Tanah sebagai bagian dari harta kekayaan dalam perkawinan perlu diketahui secara pasti siapa yang paling berhak untuk melakukan perbuatan hukum sebagai subyek hak. Subyek hak untuk tanah yang merupakan bagian dari harta bersama meliputi suami dan istri, meskipun secara yuridis tidak dipermasalahkan terdaftar atas nama suami dan/atau istri. Pada umumnya, pencatatan nama pemegang hak pada sertipikat adalah menggunakan nama salah satu pihak suami atau istri saja sehingga pihak lain yang akan melakukan perbuatan hukum terhadap tanah tersebut tidak dapat mengetahui asal usul harta tersebut apakah harta bersama atau harta bawaan.

Jika penjual memalsukan identitas dirinya dihadapan PPAT, dan mengatakan bahwa statusnya belum menikah, maka PPAT akan menuliskannya di dalam akta. Akta PPAT hanya akan mencantumkan bahwa telah terjadi peralihan hak milik atas sebidang tanah dari pihak penjual tersebut kepada seorang pembeli. Penjual tidak memerlukan persetujuan pasangan dalam melakukan perbuatan hukum mengalihkan hak atas tanah karena PPAT menganggap bahwa tanah merupakan harta bawaan. Akta kemudian menjadi bukti pendaftaran peralihan hak atas tanah satu-satunya. Hal ini dapat terjadi karena PPAT dan pejabat pendaftaran tanah bersifat pasif. Beralihnya hak milik atas tanah ke pembeli, telah membuktikan bahwa pendaftaran tanah tidak menganut asas nemo plus yuris sekaligus telah menghilangkan bagian hak dari istri penjual. Meskipun di saat bersamaan, pejabat pendaftaran tanah tetap harus melindungi pembeli yang beritikad baik dalam memperoleh, menguasai, memiliki dan mendaftarkan hak atas tanahnya.

Untuk meminimalisir potensi permasalahan di kemudian hari, kepala kantor pertanahan sebagai pejabat yang memiliki wewenang untuk menyelenggarakan pendaftaran tanah berdasarkan Pasal 6 ayat (1) PP Nomor 24 Tahun 1997 mengambil tindakan hukum atau keputusan dalam administrasi pemerintahan yang berkaitan dengan pendaftaran peralihan hak milik tanah atas harta bersama. Kebebebasan ini disebut sebagai diskresi (Freies Ermessen). Pasal 1 angka 9 UU Nomor 30 Tahun 2014 tentang Administrasi Pemerintahan menyatakan bahwa diskresi adalah Keputusan dan/atau tindakan yang ditetapkan dan/atau dilakukan oleh Pejabat Pemerintahan untuk mengatasi persoalan konkret yang dihadapi dalam penyelenggaraan pemerintahan dalam hal peraturan perundang-undangan yang memberikan pilihan, tidak mengatur, tidak lengkap atau tidak jelas, dan/atau adanya stagnasi pemerintahan.

Dalam hal pendaftaran peralihan hak milik atas harta bersama, diskresi dilakukan dengan pertimbangan sebagai berikut:

a) Upaya kantor pertanahan dalam memberikan jaminan kepastian hukum ${ }^{7}$

Sistem pendaftaran tanah di Indonesia menganut sistem pendaftaran hak dengan sistem publikasi negatif yang mengandung unsur positif. Dalam sistem publikasi ini, sertipikat berlaku sebagai alat bukti yang kuat bukan mutlak. ${ }^{8}$ Sistem ini memiliki kelemahan bahwa pihak yang namanya tercantum sebagai pemegang hak selalu menghadapi kemungkinan gugatan dari pihak lain baik secara perdata maupun Tata Usaha Negara sehingga kantor pertanahan perlu memberikan jaminan kepastian hukum kepada pemegang hak. Salah satu upaya memberikan jaminan kepastian hukum adalah dengan cara memeriksa dan meneliti kelengkapan dokumen pendaftaran peralihan hak milik atas harta bersama sesuai ketentuan perundang-undangan dan asas-asas umum pemerintahan yang baik sebagaimana diatur dalam Pasal 10 UU Adminsitrasi Pemerintahan. Asas-asas tersebut meliputi: asas kepastian, kemanfaatan, ketidakberpihakan, kecermatan, tidak menyalahgunakan wewenang, keterbukaan, kepentingan umum dan pelayanan yang baik.

b) Perwujudan peran aktif pejabat pendaftaran tanah

Meskipun pejabat pendaftaran tanah hanya wajib melakukan penelitian dan pencermatan secara formil untuk melakukan penilaian tentang mekanisme dan prosedur suatu permohonan hak atas tanah, dan tidak

\footnotetext{
${ }^{6}$ Etty Rochaeti, “Analisis Yuridis tentang Harta Bersama (gono-gini) dalam Perkawinan Menurut Pandangan Hukum Islam dan Hukum Positif”, Jurnal wawasan Hukum, Vol. 28 No 01, (2013).

${ }^{7}$ Pasal 22 Undang-Undang Nomor 30 Tahun 2014 tentang Administrasi Pemerintahan.

${ }^{8}$ Pasal 19 ayat (2) huruf c Undang-Undang Nomor 5 Tahun 1960 tentang Peraturan Dasar Pokok-Pokok Agraria (UUPA) dan Pasal 32 ayat (1) PP Nomor 24 Tahun 1997.
} 
diharuskan untuk melakukan penelaahan secara materii ${ }^{9}$, berdasarkan Pasal 6 ayat (1) Peraturan Kepala Badan Nasional Nomor 7 Tahun 2007 tentang Panitia Pemeriksaan Tanah menyatakan bahwa pejabat pendaftaran tanah memiliki tugas untuk memeriksa kelengkapan berkas permohonan hak, mengadakan penelitian dan pengkajian mengenai status tanah, riwayat tanah dan hubungan hukum antara tanah dengan pemohon, meneliti kesesuaian penggunaan tanah dengan Rencana Tata Ruang Wilayah setempat. Hal senada juga ditegaskan kembali dalam Pasal 7 ayat (2) UU Administrasi Pemerintahan yang menyatakan bahwa pejabat pemerintahan berkewajiban untuk memeriksa dan meneliti dokumen administrasi pemerintahan dalam rangka menerbitkan Keputusan Tata Usaha Negara.

c) Pemenuhan persyaratan dalam menerbitkan Keputusan Tata Usaha Negara (KTUN)

Sertipikat sebagai KTUN harus memenuhi 4 (empat) syarat ketetapan yang sah sebagaimana menurut Prof. Van der Pot yaitu: ${ }^{10}$ Ketetapan harus dibuat oleh badan yang berwenang membuatnya yang dalam hal ini dilakukan oleh Kantor Pertanahan; Ketetapan merupakan suatu pernyataan kehendak yang tidak boleh mengandung kekurangan yuridis berupa paksaan, kekeliruan, dan penipuan; Ketetapan memiliki bentuk yang telah diatur oleh peraturan perundangan; Isi dan tujuan ketetapan harus sesuai dengan isi dan tujuan peraturan dasarnya. Untuk itu agar sah sebagai KTUN, sertipikat harus memuat dokumen selengkaplengkapnya dan sejelas mungkin mengenai kepastian subyek, obyek dan hak atas tanah.

d) Perlunya dokumen lain untuk pelengkap pembuktian selain Akta PPAT

Hukum bersumber dari kebiasaan (adat-istiadat), undang-undang, yurisprudensi, traktat dan/atau doktin dan pendapat ahli hukum. Hal ini juga dapat dianalogikan untuk akta PPAT yang akan dijadikan dasar pendaftaran peralihan hak milik atas harta bersama. Akta PPAT merupakan alat bukti sempurna dikarenakan di dalam akta telah termasuk semua unsur bukti yang meliputi: tulisan, saksi, persangkaan, pengakuan, dan sumpah. ${ }^{11}$ Untuk itu, menurut ketentuan PP Nomor 24 Tahun 1997, peralihan hak atas tanah hanya dapat dibuktikan dengan Akta PPAT. Namun ketentuan ini tidak berlaku mutatis mutandis dalam semua peralihan hak atas tanah. Pasal 37 ayat (2) PP Nomor 24 Tahun 1997 menyiratkan bahwa dalam hal tertentu, Kepala Kantor Pertanahan memiliki kewenangan untuk menjadikan dokumen lain yang dianggap layak sebagai dasar mendaftarkan peralihan hak milik atas tanah yang berasal dari harta bersama perkawinan. Hal ini senada dengan sumber hukum lain yaitu Putusan Mahkamah Agung Nomor: 1363/K/Sip/1997 yang menyatakan bahwa Pasal 19 PP Nomor 10 Tahun 1961 dan Pasal 37 PP Nomor 24 Tahun 1997 secara jelas menentukan bahwa akta PPAT hanyalah suatu alat bukti dan tidak menyebut bahwa akta adalah syarat mutlak tentang sah tidaknya suatu jual beli tanah. Jual beli tanah masih dapat dibuktikan dengan alat pembuktian yang lain. ${ }^{12}$

e) Akibat perundang-undangan yang mengatur tidak jelas dan tidak lengkap

Diskresi dapat diterapkan dalam kondisi apabila peraturan perundang-undangan yang memberikan pilihan, peraturan perundang-undangan tidak mengatur, peraturan perundang-undangan tidak lengkap atau tidak jelas atau karena kondisi adanya stagnasi pemerintahan guna kepentingan yang lebih luas. Kenyataan bahwa sampai saat ini peraturan pemerintah yang khusus mengatur mengenai peralihan hak milik atas tanah belum ada sebagaimana diamanatkan oleh Pasal 26 UUPA, menyebabkan pelaksanaan pendaftaran peralihan hak atas tanah masih berpedoman kepada beberapa peraturan perundangan lain yaitu PP Nomor 24 Tahun 1997 dan PMNA Nomor 3 Tahun 1997 mengenai tata cara pendaftaran peralihan hak serta PERKABAN Nomor 1 Tahun 2010 mengenai persyaratan pendaftaran peralihan hak atas tanah. PERKABAN Nomor 1 Tahun 2010 ini tidak pula mengatur secara rinci mengenai asal-usul perolehan tanah, apakah tanah tersebut berasal dari harta bersama atau harta bawaan dalam perkawinan. ${ }^{13}$

Sementara dalam kegiatan pendaftaran peralihan hak milik tanah atas harta bersama perkawinan, potensi sengketa kepemilikan semakin besar maka kepala kantor pertanahan berupaya mencari solusi atas semua permasalahan dengan menerapkan wewenangnya untuk melakukan tindakan administrasi pemerintahan berupa penambahan dokumen persyaratan dalam pendaftaran peralihan hak milik atas harta

\footnotetext{
${ }^{9}$ Pasal 2 Peraturan Kepala Badan Nasional Nomor 7 tahun 2007 Tentang Panitia Pemeriksaan Tanah yang menyatakan bahwa "mengenai kebenaran materiil dari warkah/berkas yang diajukan dalam rangka permohonan/pengakuan hak sepenuhnya merupakan tanggung jawab pemohon".

${ }^{10}$ Bachsan Mustafa, Sistem Hukum Administrasi Negara Indonesia, (Bandung, PT. Citra Aditya Bakti, 2001), hlm 88.

${ }^{11}$ Pasal 1866 KUH Perdata.

12 Hasil wawancara dengan Endriana Kusuma Dewi, S.H., M.Kn. dan Fita Juwita Sekka S.H., M.Kn. selaku Notaris PPAT Kabupaten Lampung Timur pada hari Kamis tanggal 13 Juni 2019 Pukul 11.00 WIB.

${ }^{13}$ Hasil wawancara dengan Yeni Susanti, S.H., M.Kn., Rega Siti Fatimah, S.H., M.Kn. dan Subiyanto Tamsih, S.H., M.Kn. selaku Notaris PPAT Kabupaten Lampung Timur pada hari Kamis tanggal 13 Juni 2019 Pukul 11.00 WIB.
} 
bersama dari perkawinan. Kebijakan untuk menambahkan dokumen persyaratan sebagai pelengkap pembuktian dalam penyelenggaraan pendaftaran peralihan hak milik atas harta bersama dianggap sebagai perbuatan/tindakan penyesuaian antara pelaksanaan aturan yang ada dengan situasi yang ada di masyarakat (relevansi hukum). Hanya saja, dalam pelaksanaannya, diskresi yang diterapkan oleh Kepala Kantor Pertanahan Kabupaten Lampung Timur belum dibuat dalam bentuk tertulis sehingga tidak memenuhi asas legalitas dalam melakukan suatu tindakan administrasi pemerintahan. Diskresi dapat diterapkan dalam kondisi apabila terdapat celah hukum yang tidak mengatur di tengah perkembangan kebutuhan masyarakat yang begitu cepat dan/atau di sisi lain tidak mungkin diatur mengenai semua hal beserta detail kecilnya karena akan timbul terlalu banyak pengaturan yang terlalu mengikat dan dapat berpotensi mengurangi efektifitas aparatur Negara. ${ }^{14}$

\section{Kekuatan Pembuktian Akta PPAT dalam Pendaftaran Tanah}

Ketentuan mengenai kewajiban penggunaan akta sebagai alat pembuktian satu-satunya dalam pendaftaran peralihan hak milik atas tanah adalah seperti diamanatkan Pasal 37 ayat (1) PP Nomor 24 Tahun 1997 dan Pasal 104 ayat (1) PMNA Nomor 3 Tahun 1997. Akta PPAT sebagaimana dicantumkan dalam Pasal 1 butir (4) Peraturan Pemerintah Nomor 37 Tahun 1998 merupakan akta yang dibuat oleh PPAT sebagai bukti telah dilaksanakannya perbuatan hukum tertentu mengenai hak atas tanah atau hak milik atas satuan rumah susun. Akta PPAT tergolong akta otentik dikarenakan telah memenuhi persyaratan dibuat dalam bentuk yang ditetapkan oleh undang-undang, dibuat oleh atau di hadapan seorang pejabat umum, dan akta dibuat oleh atau di hadapan pejabat umum yang berwenang untuk membuatnya di tempat di mana akta itu di buat. Akta PPAT juga berlaku sebagai perjanjian bagi para pihak yang membuatnya, karena di dalam akta PPAT terkandung unsur-unsur dalam perjanjian seperti tercantum dalam Pasal 1320 KUH Perdata yaitu adanya kesepakatan, kecakapan, mengenai objek tertentu dan causa halal. Dengan demikian akta PPAT juga berlaku sebagai undang-undang bagi para pihak.

Selanjutnya, Pasal 1866 KUH Perdata menyatakan bahwa akta PPAT merupakan alat bukti yang sempurna dikarenakan di dalam akta PPAT telah termasuk semua unsur bukti meliputi: tulisan, saksi, persangkaan, pengakuan, dan sumpah. Meskipun akta memiliki kekuatan pembuktian sempurna secara perdata, peran PPAT dalam pembuatan akta peralihan hak atas tanah adalah pasif. PPAT hanya bertugas mencatat atau menuliskan dalam akta apa-apa yang diterangkan para pihak, tidak berhak mengubah, mengurangi atau menambah apa yang diterangkan para penghadap sehingga jika terdapat data yang palsu, maka tanggung jawab dan akibat hukum dibebankan kepada penjual, pembeli dan para saksi. Akta PPAT tidak pula memenuhi syarat sebagai Keputusan Tata Usaha Negara yang bersifat konkret, individual dan final serta tidak menimbulkan akibat hukum perdata bagi seseorang atau badan hukum perdata, karena akta merupakan formulasi keinginan para pihak yang dituangkan dalam akta yang dibuat di hadapan atau oleh Pejabat Umum. ${ }^{15}$

Dalam kasus tertentu, apabila seseorang yang tunduk pada hukum perdata ingin membeli suatu bidang tanah dari seorang penjual laki laki, maka ia tidak akan mengecek apakah bidang tanah tersebut merupakan harta bersama atau harta bawaan. Hal ini dikarenakan berdasarkan Pasal 124 KUH Perdata yang menyatakan bahwa seorang suami diperbolehkan menjual, memindahtangankan dan membebani harta bersama tanpa campur tangan istri. Jika penjual memalsukan identitas dirinya dihadapan PPAT, dan mengatakan bahwa statusnya belum menikah, maka PPAT akan menuliskannya di dalam akta. Akta PPAT hanya akan mencantumkan bahwa telah terjadi peralihan hak milik atas sebidang tanah dari pihak penjual tersebut kepada seorang pembeli. Penjual tidak memerlukan persetujuan pasangan dalam melakukan perbuatan hukum mengalihkan hak atas tanah karena PPAT menganggap bahwa tanah merupakan harta bawaan. Akta PPAT tersebut kemudian menjadi bukti pendaftaran peralihan hak atas tanah satu-satunya. Hal ini dapat terjadi karena PPAT hanya bersifat pasif dan menerima permohonan saja.

Beralihnya hak milik atas tanah ke pembeli, telah membuktikan bahwa pendaftaran tanah tidak menganut asas nemo plus yuris sekaligus telah menghilangkan bagian hak dari istri penjual. Meskipun di saat bersamaan, pejabat pendaftaran tanah tetap harus melindungi pembeli yang beritikad baik dalam memperoleh, menguasai, memiliki dan mendaftarkan hak atas tanahnya. Dengan demikian untuk

\footnotetext{
${ }^{14}$ Muhammad Yasin, dkk, Anotasi Undang-Undang Nomor 30 Tahun 2014, Jakarta: Universitas Indonesia- Center for Study Governance and Administrative Reform, (2017), hlm 115.

${ }^{15}$ Pasal 1 angka 3 UU Nomor 5 Tahun 1986 tentang Peradilan Tata Usaha Negara.
} 
memberikan jaminan kepastian hukum dalam pendaftaran tanah, kantor pertanahan tidak serta merta menrima akta PPAT sebagai bukti satu satunya peralihan hak atas tanah.

Akta PPAT masih harus dilengkapi dokumen tambahan lain berupa: fotokopi buku nikah, perjanjian perkawinan bila ada, fotokopi akta cerai, surat keterangan mengenai asal usul tanah, dan/atau surat persetujuan dari para ahli waris jika salah satu pasangan suami/istri telah meninggal dunia.

\section{Upaya Kantor Pertanahan dalam Memberikan Jaminan Kepastian Hukum Sertipikat Hak Atas Tanah}

Kepastian hukum hak atas tanah ditentukan oleh berfungsinya tiga hal, yaitu: substansi, struktur dan budaya hukum. ${ }^{16}$ Substansi hukum meliputi peraturan perundang-undangan, sistem dan tujuan pendaftaran tanah serta tata laksana pendaftaran tanah. Struktur hukum meliputi institusi yang berwenang melaksanakan pendaftaran tanah, aparat pelaksana, mitra kerja dan lembaga penguji kepastian hukum (pengadilan). Budaya hukum meliputi kesadaran hukum dan realitas sosial di masyarakat.

Muchtar Wahid menjabarkan tentang kontruksi hukum yang ingin dibangun oleh PP Nomor 24 Tahun 1997 adalah bertujuan untuk memberikan jaminan kepastian hukum mengenai subyek, obyek, dan hak atas tanah. Dari ketiga hal tersebut, di dalam penyelenggaraan pendaftaran peralihan hak milik atas harta bersama, kepastian subyek merupakan unsur paling vital karena akan berkaitan dengan upaya mencegah sengketa dan konflik pertanahan di kemudian hari.

Kepastian subyek adalah kepastian terhadap siapa yang paling berhak untuk menguasai, memiliki dan melakukan perbuatan hukum atas tanah. Penentuan subyek hak harus dinyatakan secara tegas di dalam akta PPAT. Sebagai contoh, dalam pemberian hak milik atas tanah berlaku asas nasionalitas yang berarti hanya dapat diberikan kepada Warga Negara Indonesia dan badan-badan hukum tertentu. Hak milik harus bersih dari unsurunsur asing. ${ }^{17}$ Akta harus mencantumkan identitas para pihak dan persetujuan dari suami/istri. Persetujuan suami/istri diimplementasikan dalam bentuk memberikan tanda tangan pada akta peralihan. Hal ini diperlukan sebab terhadap harta bersama berlaku ketentuan bahwa kepemilikan harta bersama dimiliki secara kolektif oleh pasangan suami istri sehingga wewenang dan tanggung jawab terhadap harta tersebut berada ditangan keduanya tanpa mempersoalkan terdaftar atas nama siapapun (Pasal 1 huruf (f) KHI dan Pasal 36 ayat (1) UU Perkawinan).

Meskipun, di dalam komparisi akta telah dicantumkan secara tegas hal-hal tersebut di atas, sebagai pelengkap pembuktian secara administrasi, pendaftaran peralihan hak milik atas harta bersama perkawinan juga harus melampirkan dokumen tambahan berupa: fotokopi buku nikah, perjanjian perkawinan bila ada, fotokopi akta cerai, surat keterangan dari kepala desa mengenai asal usul tanah, surat persetujuan dari para ahli waris jika salah satu pasangan suami/istri telah meninggal dunia.

Pengujian subyek melalui penambahan dokumen ini bertujuan untuk melindungi kepentingan para pihak yang melakukan perbuatan hukum peralihan hak. Dilihat dari sisi pembeli, adanya dokumen ini akan membantu pembuktian pejabat pendaftaran tanah dalam menerapkan asas hukum itikad baik yaitu pembeli yang memiliki niat baik untuk memperoleh, menguasai, memiliki dan mendaftarkan hak atas tanahnya. ${ }^{18}$ Dilihat dari sisi penjual, adanya dokumen ini akan membantu pembuktian pejabat pendaftaran tanah dalam menerapkan asas nemo plus yuris yakni melindungi pemegang hak atas yang sebenarnya dari tindakan orang lain yang mengalihkan hak tanpa diketahui pemegang hak yang sebenarnya. ${ }^{19}$

\section{Kesimpulan}

Berdasarkan uraian di atas, dapat disimpulkan beberapa hal yaitu: 1) Di dalam penyelenggaraan pendaftaran peralihan hak milik atas harta bersama dimungkinkan adanya diskresi oleh Kepala Kantor Pertanahan sebagai akibat dari peraturan perundang-undangan yang mengatur tidak lengkap dan jelas. Diskresi diterapkan melalui tindakan hukum administrasi berupa pemberlakuan persyaratan dokumen tambahan dalam pendaftaran peralihan hak milik atas harta bersama perkawinan berupa: fotokopi buku nikah, perjanjian perkawinan bila ada, fotokopi akta cerai, surat keterangan dari kepala desa letak tanah bahwa tanah dibeli oleh pemohon merupakan harta bersama dan/atau surat persetujuan dari para ahli waris jika

\footnotetext{
${ }^{16}$ Muchtar Wahid, Memaknai Kepastian Hukum Hak Milik Atas Tanah: Suatu Analisis dengan Pendekatan Terpadu Secara Normatif dan Sosilogis, Jakarta: Penerbit Republika, (2008), hlm. 81.

${ }^{17}$ Nabila Rosa dan FX. Sumarja, "Pemisahan Harta dalam Perkawinan Campuran Untuk Menghindari Kepemilikan Tanah Hak Milik Oleh Orang Asing", Jurnal HIMA HAN, (2018).

${ }^{18}$ Penjelasan Umum Pasal 32 ayat (2) PP 24 Tahun 1997 tentang Pendaftaran Tanah.

19 Adrian Sutedi, Sertipikat Hak Atas Tanah, Jakarta: Sinar Grafika, (2017), hlm 2.
} 
salah satu pasangan suami/istri telah meninggal dunia. Diskresi diambil berdasarkan empat pertimbangan yaitu: sebagai upaya untuk memberikan jaminan kepastian hukum pemegang hak atas tanah, perwujudan peran aktif pejabat pendaftaran tanah untuk menyajikan data yang benar di dalam daftar umum, untuk memenuhi persyaratan dalam menerbitkan suatu Keputusan Tata Usaha Negara yang sah sesuai UU Administrasi Pemerintahan, dan sebagai pelengkap pembuktian selain Akta PPAT.

\section{Ucapan Terima Kasih}

Penulis mengucapkan terima kasih kepada Universitas Lampung, dosen program studi ilmu hukum Universitas Lampung, teman-teman yang bekerja di Badan Pertanahan Nasional, dan semua pihak yang telah berkontribusi dalam penulisan jurnal ini.

\section{A. Buku}

\section{DAFTAR PUSTAKA}

Adjie, Habib. (2013). Kebatalan dan Pembatalan Akta Notaris. Bandung: Refika Aditama

Sumarja, F.X. (2015). Hak Atas Tanah Bagi Orang Asing. Yogyakarta: STPN Press.

Sumarja, F.X. (2012). Problematika Kepemilikan Tanah Bagi Orang Asing. Cetakan Pertama. Bandar Lampung: Indepth Publishing.

Harsono, Boedi. (2008). Hukum Agraria Indonesia, Sejarah Pembentukan Undang- Undang Pokok Agraria, Isi dan Pelaksanaannya. Jilid 1. Jakarta: Penerbit Djambatan.

Mustafa, Bachsan. (2001). Sistem Hukum Administrasi Negara Indonesia. Bandung: Citra Aditya Bakti.

M. Yasin, dkk. (2017). Anotasi Undang-Undang Nomor 3 Tahun 2014 tentang Administrasi Pemerintahan. Jakarta: Universitas Indonesia-Center for Study of Governance and Administrative Reform.

Sutedi, Adrian. (2012). Sertipikat Hak Atas Tanah, Jakarta: Sinar Grafika.

Wahid, Muchtar. (2008). Memaknai Kepastian Hukum Hak Milik Atas Tanah: Suatu Analisis dengan Pendekatan Terpadu Secara Normatif dan Sosilogis. Jakarta: Penerbit Republika

\section{B. Jurnal}

Etty Rochaeti, "Analisis Yuridis tentang Harta Bersama (gono-gini) dalam Perkawinan Menurut Pandangan Hukum Islam dan Hukum Positif”, Jurnal Wawasan Hukum, Vol. 28 No. 01, (2013).

Nabila Rosa dan FX. Sumarja, "Pemisahan Harta dalam Perkawinan Campuran Untuk Menghindari Kepemilikan Tanah Hak Milik Oleh Orang Asing”, Jurnal HIMA HAN, (2018).

Upik Hamidah, "Pembaharuan Standar Prosedure Operasi pengaturan (SOP) Pelayanan Pendaftaran Peralihan Hak Milik Atas Tanah Karena Hibah Wasiat Berdasarkan Alat Bukti Peralihan Hak", Fiat Justisia Jurnal Ilmu Hukum, Vol. 6 No. 2, (2012). 